\title{
DEBATABLE ISSUES OF PERSONAL VALUES IN THE CONTEXT OF HARMONIZATION OF EDUCATIONAL STANDARDS OF UKRAINE AND THE EU
}

DYSKUSYJNE KWESTIE WARTOŚCI OSOBISTYCH W KONTEKŚCIE HARMONIZACJI STANDARDÓW EDUKACYJNYCH UKRAINY I UE

\author{
Liudmyla Shulhina, Professor \\ National Technical University of Ukraine "Igor Sikorsky Kyiv Polytechnic Institute", Industrial Marketing Department \\ Prospect Peremohy, 37, Kyiv 03056, Ukraine \\ shulm@ukr.net•ORCID 0000-0001-9554-6185
}

\section{Hanna Zhaldak, PhD}

National Technical University of Ukraine "Igor Sikorsky Kyiv Polytechnic Institute", Management Department

Prospect Peremohy, 37, Kyiv 03056, Ukraine

ann17@i.ua •ORCID 0000-0003-3421-3648

DOl: 10.2478/minib-2020-0028

\section{ABSTRACT}

The necessity and urgency of the gap reducing between the pace of technological and humanitarian development of society in order to prevent the risks caused by the insufficient level of training of users of modern technologies is pointed out. The expediency of strengthening of the humanitarian component in the educational process is substantiated. Based on the method of desk content research, some structural and substantive differences between normative documents are illustrated, the positive influence of harmonization of legislation in the field of education is shown, as well as the development of educational standards on the formulation of personality values in these documents. The group of moral and ethical characteristics of students and teachers of Ukraine and Poland was evaluated. A relatively low level of presence of characteristics that make up the values of the representatives of the surveyed groups is established. Positive and negative dynamics of various indicators are revealed. A comparative evaluation of the studied characteristics between the representatives of Ukraine and Poland was carried out. An explanation of the identified differences is given.

Key words: values of personality, moral and ethical characteristics, educational standards, harmonization of standards 


\section{ABSTRAKT}

W artykule została wskazana konieczność i pilność zredukowania przepaści pomiędzy prędkością technologicznego i humanitarnego rozwoju społeczeństwa w celu zapobieżenia zagrożeniom spowodowanym przez niewystarczający poziom wyszkolenia użytkowników nowoczesnych technologii. Pokazano celowość wzmocnienia aspektu humanitarnego w procesie edukacyjnym. Bazując na metodzie badania merytorycznego „zza biurka”, zilustrowano niektóre ze strukturalnych i merytorycznych różnic pomiędzy dokumentami normatywnymi, wykazano pozytywny wpływ harmonizacji ustawodawstwa na polu edukacji, jak również rozwój standardów edukacyjnych na podstawie sformułowanych wartości osobowości przedstawionych w tych dokumentach. Poddano ocenie zespół moralnych i etycznych cech studentów i wykładowców z Ukrainy i z Polski. Ustalono względnie niski poziom obecności cech tworzących wartości reprezentantów ankietowanych grup. Ujawniono dodatnią i ujemną dynamikę różnych wskaźników. Dokonano oceny porównawczej badanych cech pomiędzy przedstawicielami Ukrainy i Polski. Podano wyjaśnienie zidentyfikowanych różnic.

Słowa kluczowe: wartości osobowości, cechy moralne i etyczne, standardy edukacyjne, harmonizacja standardów

JEL: A13, D63, 125, J88

\section{Introduction}

Accelerated development of various technologies, caused mainly by the dynamics of changes in information technology, affects both all spheres of human life (regardless of type of activity) and all levels of organization of human life in society from individuals and their groups within one location up to global scale. Having maximally generalized the consequences of technological development, we reduce them to two positions, which in our opinion are the most obvious: 1) increasing of the pace of people's lives and 2) increasing of the scale of their activities. Each of these two features of modernity, of course, opens up incredibly attractive horizons of success for adequately prepared individuals or groups of such individuals, united in enterprises, organizations, alliances, etc. 
However, the authors of the proposed article consider it necessary to focus on the expression "adequately prepared personality", our interpretation of this expression, we will consider in detail below. We mean that in the opposite case, i.e. if a person is unprepared or the level of their readiness to perform certain functions is questionable, along with the acquired technological capabilities in today's accelerated and globalized world, the risks also increase. It is clear that the higher the position held by such a person, and the greater the scale of their influence, the higher level of risk and of (negative) consequences of their activities.

We have no reason to say that the very awareness of the likelihood of risks from the activities of influential, active and unprepared users of modern technology has been the primary reason for the development of educational standards in all countries. Analysis of sources indicates the predominance of socio-economic and political-legal drivers of the initiation of standard-forming activities. However, the growing mismatch between the expected and real results of socio-economic development in all countries in the context of global problems deepening in the world, as well as a significant number of unsuccessful solutions to solve these problems prompts us to ask a number of questions. The key of them is seen as follows: how to anticipate and fix in educational standards the safeguards of the gap between the pace of technological and humanitarian development of society.

In other words, we are convinced of the relevance, and hence the need for a deeper study of this assumption: the values in the current educational standards are not written clearly enough (or not described at all), resulting in incomparably greater attention paid to the formation of special competencies of students to perform their functions as specialists in a certain field than the attention to their development as highly moral and physically developed individuals, capable of creative work and the formation of a future, more efficient society. One of the consequences of this disproportion, which is the subject of our study, we formulated as follows: the pace of technology development in modern society is much ahead of the development of such a person, which could be characterized as highly humane and socially responsible. Realizing that the problem raised is extremely complex, multifaceted and ambiguous, we focused our attention solely on studying the possibility of defining and in the long run to improve the tools to solve it, including through educational standards. 


\section{The purpose of the article and research methodology}

The purpose of the proposed article is to present the results of a comparative analysis of the content of educational laws and standards, as well as research data on the values of personality on the example of students and teachers of Ukraine and the EU (on the example of Poland).

To achieve this goal, three groups of methods were used. The first group of methods included cabinet and content analysis, which included research of Ukrainian and foreign regulatory and scientific sources, namely: the legal framework for education in Ukraine and the EU, regulations that are governing this process, articles and monographs, which set out the results of research of processes of standards harmonization.

The second group of methods consisted of included and not included field research, in which the units of the survey were participants in the educational process: 436 students, 257 teachers and representatives of the administration of Ukrainian and Polish universities.

Data analysis was performed using the Statistics program. The research period is $2002-2020$.

\section{Theoretical basis of the proposed study}

Throughout the historical path of human development, philosophers, writers, politicians, and others constantly referred to the concepts of "good" and "evil", "justice" and "injustice", "morally" or "immorally" and finally "humanely" or "inhumanely". We will limit ourselves here to the quotations of those researchers who have deeply studied these categories, and the definitions of whom we consider the most accurate and that best reflect the essence of these always relevant concepts.

Morality (from the Latin morales - moral, mores - customs) - is a historical phenomenon. Its requirements, norms, principles and ideals are determined by socio-political relations and socio-economic formation. In the philosophical literature, morality is seen as a form of social consciousness, which reflects and consolidates the ethical qualities of social reality (good, justice, etc.) (Moral'; Syla, 2007). Adherence to moral norms is one of the conditions for effective interaction of individuals in the process of joint 
activities in communication. They allow a person to evaluate their own and others' actions, compare them with the standard, regulate relationships with other people (Philosophs'kyy, 2002). We emphasize that moral norms are the regulator not of the inner world of man, but of relations between people.

One of the components of moral education is humanistic one, which is based on the principle of humanism. According to the etymology, the category "humanism" (from the Latin humanus - human) is defined as a historically changing system of views that determines the value of man as a person, his right to freedom, happiness, development and manifestation of their abilities, which considers human well-being as the criterion for evaluating of social institutions, and the principles of equality, justice and humanity as the desired norm of relations between people (Entsyklopediia, 2020). Humanism not only recognizes love and respect for man as its basic principle, but also raises the question of creating of truly humane human conditions in society itself, which is a necessary condition for the harmonious development of the individual. The basic categories of morality, on which humanism is based as a worldview, are freedom, goodness, duty and necessity (Tyckonovych, 2019).

Humanity is a personality feature, the content of which is determined by the principles of humanism. Humanity is a set of such features: respect, sensitivity, sense of justice, trust, self-criticism, courage. As a moral characteristic of a social personality, humanity is characterized by initiative and courage in combating selfish forms of behavior of others, satisfaction from selfless care for people, focus primarily on the positive in people, recognition of man, his interests, constant focus on man and compassion for him.

The category of humanity is inextricably linked to the concept of personality. Personality is the highest degree of spiritual development of a person, characterized by a stable set of socially important features that together form the individual as a unique subjectivity who is able to master and change the world (Antychna Philisophiya, 2020).

In turn, the analysis of the just mentioned properties inevitably leads to the next important characteristic of the personality as responsibility. It can be defined quite broadly as a moral characteristic of the individual, which determines his willingness to accept and perform certain responsibilities that meet their own life principles, the requirements of the group, team and society in general (Ckytra, 2013). 
It is clear that not only humanity and responsibility, but also many other human virtues, which we do not consider here, are derived from a set of values of the individual. According to (Vsemirnaya entsyklopiediya, 2001) values are, first of all, giving preference or denying of certain meanings as the basis of the organization of life and (un)willingness to act in accordance with them. It follows that values determine the general direction of the individual, the hierarchy of individual preferences, target and motivational programs, the level of aspirations and prestigious advantages, the degree of readiness and determination through volitional components and through the implementation of their own "project" of life (Shaygorods'kyy, 2010).

There are different approaches in a literature to the definition and characterization of personality values. We were based on the approach set out in the concept of the "New Ukrainian School", according to which the student's values $(\mathrm{V})$ have the following components: moral and ethical (dignity, equality, justice, tolerance and cultural diversity, care, honesty, trust); socio-legal (rule of law, intolerance of corruption and favoritism, patriotism, environmental and ethical value, social responsibility) and personality-oriented (self-realization, leadership and freedom) (Tsinnisni..., 2019).

\section{Reflection of the content of values in the legislation and standards of education of Ukraine and Poland}

The reflection of the content of $\mathrm{V}$, declared in the mentioned Concept, is found in the laws on education and higher education, as well as educational standards. For example, we consider the formulation of the general competencies of a bachelor in marketing (Table 1).

The Table 1 shows only some quotations from the analyzed documents, a brief comparison of which with the selection of semantic differences between them is illustrated in the Table 2 . 


\section{Table 1. Comparison of formulations of education goals in the legislation and standards of Ukraine and Poland}

\begin{tabular}{|c|c|}
\hline Goals of higher education in Poland & Goals of higher education in Ukraine \\
\hline $\begin{array}{l}\text { To provide the knowledge necessary for active and } \\
\text { creative participation in the life of the modern world } \\
\text { community } \\
\text { - To form values important for the successful } \\
\text { functioning of a free democratic society, such as } \\
\text { tolerance, respect for rights, including minority rights, } \\
\text { love of freedom, a sense of solidarity, and to form an } \\
\text { image and respect for the idea of the common good } \\
\text { - Develop a sense of social belonging and patriotism } \\
\text { To learn to combine active and harmonious } \\
\text { cooperation at work, in the family and local } \\
\text { communities with the ability to choose and set their } \\
\text { own goals and achieve them. It should teach you to be } \\
\text { responsible to yourself and at the same time be } \\
\text { responsible to others }\end{array}$ & $\begin{array}{l}\text { Comprehensive development of man as a person and } \\
\text { the highest value of society, his/her talents, intellectual, } \\
\text { creative and physical abilities, formation of values and } \\
\text { competencies necessary for successful self-realization, } \\
\text { education of responsible citizens who are able to make } \\
\text { conscious social choices and direct their activities for } \\
\text { other people and society. Enriching on this basis of the } \\
\text { intellectual, economic, creative, cultural potential of the } \\
\text { Ukrainian people, raising of the educational level of } \\
\text { citizens to ensure the sustainable development of } \\
\text { Ukraine and its European choice }\end{array}$ \\
\hline Educational outcomes in Poland & Educational outcomes in Ukraine \\
\hline $\begin{array}{l}\text { - Learning to learn } \\
\text { - Ability to think critically } \\
\text { - Knowledge of two foreign languages } \\
\text { - Ability to freely use the basics of mathematics and } \\
\text { knowledge of the nature around us and modern } \\
\text { methods of information transfer } \\
\text { - Communication skills } \\
\text { - Ability to understand and use information that is } \\
\text { typical and most common in everyday life; at work, at } \\
\text { school, in public life and in local communities }\end{array}$ & $\begin{array}{l}\text { GC3. Ability to abstract thinking, analysis and } \\
\text { synthesis } \\
\text { GC4. Ability to learn and master modern knowledge } \\
\text { GC9. Skills in the use of information and } \\
\text { communication technologies } \\
\text { GC10. Ability to communicate in a foreign language } \\
\text { GC13. Ability to work in an international context } \\
\text { GC14. Ability to act responsibly and consciously in } \\
\text { social sphere }\end{array}$ \\
\hline
\end{tabular}

Notes:

Given the different structure of regulations in Ukraine and Poland, the main criterion for choosing of sources was the definition of learning objectives.

$\mathrm{GC}$ - general competencies.

Source: Ustawa, 2020; Zakon Ukrayiny, 2014; Standart, 2018. 


\section{Table 2. The part of content analysis of educational goals in the legislation of Ukraine and Poland}

\begin{tabular}{|c|c|}
\hline Goals of higher education in Poland & Goals of higher education in Ukraine \\
\hline $\begin{array}{l}\text { Emphasis on belonging to the "modern world } \\
\text { community" }\end{array}$ & $\begin{array}{l}\text { Emphasis on belonging to "society" (without further } \\
\text { clarification) }\end{array}$ \\
\hline Additional description of society as a "free democratic" & No description \\
\hline $\begin{array}{l}\text { Highlighted values:... tolerance, respect for rights, } \\
\text { including the rights of minorities, love of freedom, a sense } \\
\text { of solidarity, as well as to form an image and respect for } \\
\text { the idea of the common good }\end{array}$ & $\begin{array}{l}\text { The values necessary for successful self-realization of } \\
\text { competencies of education of responsible citizens who } \\
\text { are capable of conscious public choice and direction of } \\
\text { the activity for the benefit of other people and a society } \\
\text { are allocated. }\end{array}$ \\
\hline $\begin{array}{l}\text { The need to develop a sense of social belonging and } \\
\text { patriotism is highlighted separately }\end{array}$ & No description \\
\hline$\ldots$ & $\ldots$ \\
\hline Educational outcomes in Poland & Educational outcomes in Ukraine \\
\hline Ability to think critically & Ability to abstract thinking \\
\hline Knowledge of two foreign languages & Ability to communicate in a foreign language \\
\hline & \\
\hline
\end{tabular}

Source: results of authors' research.

Further analysis of the documents showed that the developers of standards of higher education in Ukraine of the first (bachelor's) level considered general competencies as a humanitarian part of the expected educational outcomes and noted some values of the individual in the GC. For instance: GC1. The ability to exercise their rights and responsibilities as a member of society, to realize the values of civil (free democratic) society and the need for its sustainable development, the rule of law, human and civil rights and freedoms in Ukraine. GC2. Ability to preserve and multiply moral, cultural, scientific values and achievements of society based on understanding of the history and regularity of development of the subject area, its place in the general system of knowledge about nature and society and in the development of society, techniques and technologies, use of 
different types and forms of physical activity for active recreation and leading of a healthy lifestyle (Standart..., 2018).

Thus, based on the content analysis of the coherence of the $\mathrm{V}$ of individual in the provisions of educational standards of Ukraine and Poland, the preliminary conclusion can be formulated as follows: despite some structural inconsistencies and lack of attention to patriotism, tolerance, respect for rights (including minority rights), the need to think critically (and not just abstractly), knowledge of at least two foreign languages (not one) and some other accents that are necessary in our opinion, the analyzed documents are very close in content, at least at the level of declarations.

In addition, the very important value-oriented documents have been developed for the regulation of the educational process at the stages of organization and control over the implementation of the provisions of the law and standards in the universities of Ukraine. For example, the Regulations on the organization of the educational process (Polozhennia..., 2020) defines the regulatory framework, basic principles and language of learning, informs about the levels and degrees of higher education, educational programs, planning of the educational process, forms of its organization and others.

In the context of our study, the following section of the Regulation draws attention: "Ensuring the quality of higher education and informatization of the educational process at the university." This section devotes enough space to the technical and technological support of the educational process but at the same time in matters of ethics and $\mathrm{V}$ is limited to a brief mention of the need to develop a culture of academic integrity, in which the main emphasis is on preventing and detecting plagiarism in academic texts. At the same time, the Commission on Ethics and Academic Integrity and the University's Code of Honor are named as important regulators of possible moral and ethical inconsistencies.

It should be noted that the development of the University Code of Honor (Kodeks..., 2015), which is designed to become another factor in the observance and development of $\mathrm{V}$ for employees and students, is currently a positive trend in the activities of Ukrainian universities. The sections of the Code analyzed by us set out the general moral principles and rules of ethical behavior, norms of ethical behavior of students and employees, as 
well as the policy of academic integrity of the University. Thus, the provisions declared in the Code can be considered as a detailed description of the behavior of individuals with high moral values, therefore, the content of the Code together with the requirements of educational standards analyzed above were the basis for the development of the program of the second stage of our study.

\section{The results of field research of personality values in the universities of Ukraine and Poland}

The expected result of the analysis of the documents' content (educational standards, regulations, codes, etc.), similar to the above and developed in various universities in Ukraine and Poland, was the fact that they all declared high moral principles and norms of behavior of participants in the educational process. This is not surprising given the formulation of educational goals in the relevant laws / educational standards and the development and detailing of these goals in derived documents. Therefore, the purpose of the next stages of our study was to establish the density of the links between 1) the declaration of the $\mathrm{V}$ in these documents and 2) their implementation by the participants of the educational process in a real life.

The research was based on the following chain of assumptions that characterize the ideal (i.e., not achieved, but desirable) moral and ethical state of the university environment:

- firstly, the humanitarian goals of education (including higher education) have existed for a long time, because the predecessors of modern documents (for example, the Law of the USSR "On Education", etc.) had the similar formulations, i.e. these goals have been tested over time. It follows that the $\mathrm{V}$ of teachers for this long time to this day have had to grown into strong beliefs and models of behavior that would indicate their high moral and ethical and other life principles;

- secondly, the implementation of these principles in the relevant models of behavior is the basis for the perception of teachers and university administration by other reference groups of society (including students) 
as a true elite of society, which these groups seek to follow, thereby gradually improving society;

- thirdly, on the scale of evolution society under the influence of educators and their students gradually improves all indicators that characterize the level of development of different aspects of public life, namely: the state of the economy, political and legal system, ecology, medicine, life expectancy and quality of life, crime rate, aggression, etc.

This logical chain of ideal implementation of $\mathrm{V}$ could be continued by detailing at different levels: individuals, families, communities, nations and even humanity. However, the reality proves the inexpediency of such a continuation, giving almost daily examples that characterize the state of society in general and university communities in particular is far from the ideal one. This is also evidenced by a fragment of the generalized results of the behavior monitoring of members of two reference groups of Ukrainian universities (students and teachers) for a long time (2002-2020), which is presented in Figure 1 in the form of a semantic differential.

\section{Figure 1. Changing of the configuration of profiles of value orientations}

for students and teachers of Ukraine in 2002-2013 and 2014-2020

\begin{tabular}{|c|c|c|c|c|c|c|c|c|c|c|c|c|}
\hline \multirow{2}{*}{$\begin{array}{l}\text { Personality } \\
\text { characteristics }\end{array}$} & \multicolumn{6}{|c|}{ for students } & \multicolumn{6}{|c|}{ for teachers } \\
\hline & 2 & 3 & 4 & 5 & 6 & 7 & 2 & 3 & 4 & 5 & 6 & 7 \\
\hline Dignity & & & & & & & & & & I & & \\
\hline Equality & & & & & & & & & & & & \\
\hline Justice & & & & & & & & & & & & \\
\hline Tolerance & & & & & & & & & & & & \\
\hline Care & & & & & & & & & & & $\cdots$ & $\because$ \\
\hline Honesty & & & & & & & & & & & & \\
\hline Trust & & & & & & & & & & & & \\
\hline
\end{tabular}

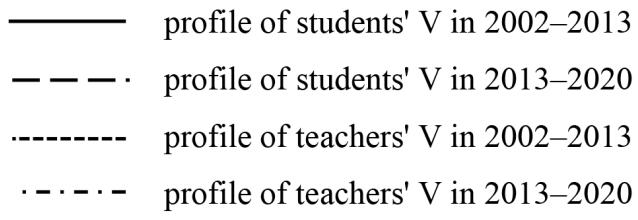

Source: own elaboration. 
Several generalizations were made to form the profiles of the $\mathrm{V}$ of the participants of the educational process (Figure 1). Firstly, we used the arithmetic mean value of estimates of certain personality characteristics obtained during the observation of representatives of one reference group or one "nest", where the "nest" is a group of students of a certain specialty. Secondly, these estimates were averaged between different "stratum", where "stratum" is the year of study, however, the identified differences did not give grounds to consider students of different years of study as representatives of different stratum. Thirdly, the same operation was performed sequentially at the second and third levels of "nests" - faculties and universities. Fourthly, we found the average within these two study periods. Fifthly, at each stage observers' assessments were reconciled, and the judgments of other participants in the educational process were also taken into account.

The sequence of generalizations described above at the first stage for teachers took the form of determining of assessments within the "nests" that were formed on the basis of the teacher's position in the team by two criteria: a) among scientists — graduate student, Ph.D., Doctor of sciences; b) among officials - assistant, senior lecturer, associate professor, professor, head of the department, dean). In the second stage, the estimates were averaged between the "nests".

It is also important to note that the semantic differential had a 10-point scale, however, the scores did not exceed the value of 6 points, except for one characteristic in the group of teachers in the second period. We explain the low scores by the discrepancy between, on the one hand, the expectations of observers based on the above high educational goals, and, on the other hand, the observed behavior of students and teachers, through which they assessed the presence of certain positive Vs in their values. The scale of the analyzed characteristics of the personality through which its Vs are found, represents group of moral and ethical properties of the person which presence can be estimated on the basis of set of behavioral signs.

During the analysis of the obtained data, several phenomena were identified, which in our opinion deserve increased attention.

First: the largest differences between grades in both subgroups were found within the first level of the nest, i.e. - one student group and one scientific and/or position of teachers. This confirmed the well-known thesis about the formation of personality before entering the university, and 
hence - a slight impact on students of such factors as specialization, year of study, faculty and/or university, as well as scientific or job position - on teachers. In other words, the estimates that were subject to the first averaging had the largest amplitude of values, and all the others were at the level of statistical error. In addition, the estimates in both subgroups were quite close, and this allowed us to formulate two assumptions: 1) status and age have a relatively small impact on already formed values; 2) students are really a reflection of the low level of Vs of those individuals and social groups that have influenced them throughout their lives.

Second: the 18-year study was divided into two periods due to significant differences in the data of both subgroups after 2013. In the subgroup of students, the highest growth is observed in the following indicators: "Dignity", "Equality" and "Honesty". At the same time, the presence of the "Care" characteristic has significantly decreased. We believe that the main factors of these changes in the Vs of students were the following: the impact of the events of the Revolution of Dignity 2013-2014 on the self-perception and rethinking of the Vs by young people, as well as the change of generations. In 18 years, a new generation has grown up, which is largely a product of the intensification of information technology, including information wars, which certainly affected the level of cynicism in the perception of reality.

Third: the rather low ratings of such characteristics as "Trust", "Tolerance", "Honesty" and "Justice" are noteworthy. Moreover, if the first three characteristics of students were improved in the second period, then teachers have a deterioration, albeit slight. This may have been influenced by inflated expectations of education reform, which has undergone several vector changes from the beginning. The negative impact of the lack of a permanent vector and adequate development strategy was exacerbated by the premature decision to expand the autonomy of universities, which their administration used mainly to build bureaucracy and narrow the rights and freedoms of employees. It is clear that this was also an additional factor in the deterioration of faith in justice in both groups.

Fourth: the dynamics of the "Care" indicator was opposite in the study groups, due to the difference in functions between students and teachers. Teachers of Ukrainian universities, who have recently faced a declining trend in the number of students (including due to study abroad), as well as the risks caused by COVID-19, are increasingly expressing their concern for 
students. At the same time, students due to the youthful maximalism, as well as the reasons described above, on the contrary, are characterized by a higher level of selfishness and egocentrism and focus more on their own person than on caring for other people.

In search of an answer to the question of the possible positive impact of harmonization of educational standards of Ukraine with EU standards on a deeper perception of Vs by students and teachers, we compared the results of evaluation of similar characteristics of Polish and Ukrainian university representatives (Figure 2).

\section{Figure 2. Comparison of the configuration of profiles of value orientations} of students and teachers for Ukraine and Poland in 2014-2020

\begin{tabular}{|c|c|c|c|c|c|c|c|c|c|c|c|c|}
\hline \multirow{2}{*}{$\begin{array}{c}\text { Personality } \\
\text { characteristics }\end{array}$} & \multicolumn{6}{|c|}{ for students } & \multicolumn{6}{|c|}{ for teachers } \\
\hline & 3 & 4 & 5 & 6 & 7 & 8 & 3 & 4 & 5 & 6 & 7 & 8 \\
\hline Dignity & & & & & & & & & & & & \\
\hline Equality & & & & & & & & & & & & \\
\hline Justice & & & & & & & & & & & & \\
\hline Tolerance & & & & & & & & & & & & \\
\hline Care & & & & & & & & & & & & \\
\hline Honesty & & & & & & & & & & & & \\
\hline Trust & & - & & & & & & & I & & & \\
\hline
\end{tabular}

- - - V profile of students of Ukraine

-.-..- V profile of teachers of Ukraine

........... V profile of students of Poland

- - $-\quad$ V profile of teachers of Poland

Source: own elaboration.

If in the process of the Vs assessing of students and teachers of Ukraine the starting point was the definitions in the normative documents, then for a similar assessment of Polish education representatives the basis for comparison was the comparative characteristics of the Ukrainian representatives. 
According to the data of the Figure 2, despite the proximity of Ukraine and Poland in many respects (geographical location and natural conditions; historical, political, socio-economic and cultural development; similarities of mentality and language), the configurations of the $\mathrm{V}$ profiles of the studied groups largely did not match. All others received higher marks except of "Equality". We explain this fact, that can be described as "more pronounced characteristics in the behavior of the individual", for the several reasons.

Firstly, Poland was much more influenced by rational European civilization (for various reasons) for a much longer period of time than Ukraine. Secondly, even in 1939-1980, when both Poland and Ukraine were under the influence of the values promoted by the Soviet empire, Poland did not destroy such traditions, religious and other cultural institutions that for centuries formed the Vs of the population, as it happened in Ukraine. Thirdly, since Poland's accession to the EU in 2004, the country has received multibillion-dollar investments, and thus a significant boost to socio-economic and other types of development, that formed a relatively high level of characteristics such as "Justice", "Tolerance", "Care", "Honesty" and "Trust" - especially for the younger generation.

At the same time, the characteristic "Equality" received a much lower rating, that in our opinion is again explained by the strength of traditions and the perception of social inequality as a typical feature of any society. Traditions of respect for elders, leaders, parents, teachers, etc. in Poland are much more pronounced than in Ukraine, which is often manifested in the demonstration of their own "lower" position in communication with representatives of the "higher" position. In addition, Polish society compared to Ukraine does not have such signs of acute social inequality, so its citizens are more tolerant of those examples of inequality that they consider acceptable.

The data obtained during the observation, presented in this article, were confirmed by the data collected by the method of in-depth interviewing of participants in the educational process. However, given the limit on the volume of publication allowed, these data together with proposals for the application of a systematic approach to eliminate the identified trends will be presented in the next article. 


\section{Conclusions}

The growing gap between the pace of technological and humanitarian development of society increases the likelihood of various risks caused by the lack of preparedness of performers to use modern technologies. After all, the latest technologies are often characterized by a significant speed of operations and scaling of effects, which, in addition to special knowledge in the subject area also requires a high level of responsibility and other characteristics that make up the concept of "personality values". This encourages scientists to look for ways to reduce and, in the long run, the full decrease of the above gap. The authors see one of the ways to solve the problem in strengthening of the humanitarian component in the educational process.

To substantiate the feasibility of such enhancement, the special studies were conducted by the method of desk content research, as well as included and not included observation. The analysis of the documents showed that in the process of harmonization of legislation in the field of education, as well as the development of educational standards, the normative documents declare in detail the need for education of high moral personality with clearly defined values.

At the same time, the evaluation of the group of moral and ethical characteristics of students and teachers of Ukraine and Poland (as the closest neighbor - a member of the EU) showed a relatively low level of presence of characteristics that indicate the values of the representatives of the surveyed groups. The study revealed trends in the growth of indicators like "Dignity" and "Equality", which indicates an increase in the need for these characteristics in real life. The assessment of such characteristics as "Trust", "Tolerance", "Honesty" and "Justice" needs to be strengthened, especially for teachers in Ukraine.

Comparison of the studied characteristics between the representatives of Ukraine and Poland revealed higher scores on all parameters, except for the characteristic of "Equality". We explain this by the better preservation of traditional values in Polish society, compared to Ukrainian, as well as a higher level of socio-economic and legislative development.

Thus, the results of the observation presented in this article indicate the lack of presence in the complex characteristics of modern personality of those important value orientations that would indicate the willingness of people who make up society to realize the possible risks of new technologies and ensure 
their safe use at all levels. These results were also confirmed and deepened based on the method of in-depth interviews with participants in the educational process of both countries. The authors are convinced of the need to apply a systematic approach to improving the described situation. A detailed description of the authors' proposals will be published in the next article.

\section{Acknowledgements}

This paper was created within the project according to the joint project of National Technical University of Ukraine "Igor Sikorsky Kyiv Polytechnic Institute", Erasmus+ Jean Monnet Fund and Education, Audiovisual and Culture Executive Agency, supported by the EC "European business models: transformation, harmonization and implementation in Ukraine" No 587138-EPP-1-2017-1-UA-EPPJMO-MODULE. Project registration number $2017-2173$ / $001-002$.

\section{References}

1. Antychna Philisophiya (Ancient Philosophy). (2020). Retrieved from https://sites.google.com/site/anticnafilosofia/osobistist-u-filosofiie

2. Ckytra, V. (2013). Teoretychni aspekty vyznachennia zmistu poniattia "vidpovidal'nist' osobystosti. Naukovi zapysky, Seriia: pedagogichni nauky, 122, 382-389.

3. Entsyklopediia suchasnoyi Ukrayiny (Encyclopedia of Modern Ukraine). (2020). Retrieved from http://esu.com.ua/search_articles.php?id=24649

4. Kodeks chesti Natsional'nogo tecknichnogo uniwersytetu Ukrayiny "Kyyivs'kyy politecknichnyy instytut" (Code of Honor of the National Technical University of Ukraine "Kyiv Polytechnic Institute"). (2015). Retrieved from https:/kpi.ua/code

5. Moral'; Syla (Morality, Strength). (2007). Literaturoznavcha entsyklopediia u 2 t. (p. 76). Kyiv: VTs "Akademiia".

6. Philosophs'kyy entsyklopedychnyy slovnyk (Philosophical encyclopedic dictionary). (2002). Instytut Philosophii im. G.S. Skovorody Natsional'noi Akademii Nauk Ukrainy, Kyiv: Abrys, 397-398.

7. Polozhennia pro organizatsiyu osyitniogo procesu $v$ KPI im. Ihora Sikorskogo (Regulations on the organization of the educational process in KPI. Igor Sikorsky). (2020). Retrieved from https://kpi.ua/regulations.

8. Shaygorods'kyy, Yu. (2010). Tsinnisni oriientatsiyi osobystosti: formalizovana model' tsilisnogo, bagatoaspektnogo analizu. Sothial'na psyckologiya, 1(39), 94-106. Retrieved from https://core.ac.uk/reader/77240790 
9. Standart vyshchoyi osvity Ukrayiny: pershyy (bakalavrs'kyy) riven', galuz' znan' 07 — Upravlinnia ta Administruvannia, Spetsial'nist' 075 Marketyng (Standard of higher education of Ukraine: first (bachelor's) level, field of knowledge 07 - Management and administration, specialty $075 \quad$ - Marketing). (2018). Retrieved from https://mon.gov.ua/storage/app/media/vishcha-osvita/zatverdzeni\%20standarty/ 12/21/075-marketing-bakalavr.pdf

10. Tsinnisni oriientyry suchasnoyi Ukrayins'koyi shkoly (Values of the Modern Ukrainian School). (2019). Ministerstvo Osvity i Nauky Ukrayiny. Retrieved from https://mon.gov.ua/storage/app/media/Serpneva\%20conferentcia/2019/PresentasiaRoman-Stesichin.pdf

11. Tyckonovych, V. (2019), Humannist' osobystosti: sutnist' ta struktura (Humanity of personality: essence and structure). Pedagogika ta psyckologiia, 55, 90-98.

12. Ustawa z dnia 14 grudnia 2016 r. Prawo oświatowe. Dz.U. z 2020 r. poz.910. Retrieved from https://www.prawo.vulcan.edu.pl/przegdok.asp?qdatprz=akt\&qplikid $=4186$

13. Vsemirnaya entsyklopiediya, Philosophiya (World encyclopedia. Philosophy) (2001). Minsk.

14. Zakon Ukrayiny "Pro vyshchu osvitu" vid 01.07.2014 No 1556-VII (Law of Ukraine "On Higher Education" from 01.07.2014 No 1556-VII), Retrieved from https://zakon.rada.gov.ua/laws/show/1556-18\#Text

Liudmyla Shulhina, Professor, Doctor of Economics, Professor of the Industrial Marketing Department at the National Technical University of Ukraine "Igor Sikorsky Kyiv Polytechnic Institute", Ukraine author of 321 publications (215 scientific and 106 educational-methodical), of which 3 monographs were published in Poland, 8 monographs consisting of 2-3 authors - in Ukraine, as well as 34 articles - in scientific publications of foreign countries (Poland, Estonia, Russia, Belarus, Slovakia, Bulgaria, Czech Republic): 21 articles were published in English, 9 - in Polish and $4-$ in Russian. Scientific supervisor of 8 postdoctoral students, who successfully protected their theses and are $\mathrm{PhD}$ now. Academic Coordinator of the Project "European business models: transformation, harmonization and implementation in Ukraine", No 587138-EPP-1-2017-1-UA-EPPJMO-MODULE.

Hanna Zhaldak, PhD (Economics), Associate Professor, Associate Professor of the Management Department at the National Technical University of Ukraine "Igor Sikorsky Kyiv Polytechnic Institute", Ukraine - author of 67 publications, of which 2 monographs, as well as 10 articles - in scientific publications of foreign countries (Poland, Russia, Bulgaria, Czech Republic): 7 articles were published in English, 3 - in Russian. Participant of the Project "European business models: transformation, harmonization and implementation in Ukraine", No 587138-EPP-1-2017-1-UA-EPPJMO-MODULE. 